\title{
ANALISIS STRUKTUR KOGNITIF MAHASISWA PADA KONSEP HUKUM NEWTON
}

\author{
Deviliana RanteTampang, I Komang Werdhiana, Syamsu \\ Devilia rantetampang@yahoo.co.id \\ Program Studi Pendidikan Fisika FKIP Universitas Tadulako \\ Jl. Soekarno Hatta Km. 9 Kampus Bumi Tadulako Tondo Palu - Sulawesi Tengah
}

\begin{abstract}
Abstrak - Penelitian ini bertujuan untuk mendeskripsikan struktur kognitif mahasiswa pada konsep hukum Newton. Struktur kognitif adalah rangkaian pengetahuan seseorang terhadap suatu materi yang diperoleh dari pengalaman dalam kehidupan sehari-hari serta berdasarkan konsep-konsep fisika yang telah dipelajari sebelumnya. Penelitian ini merupakan penelitian deskriptif-kualitatif. Subjek penelitian berjumlah 26 orang. Tes kata kunci digunakan dalam pengumpulan data dan menentukan responden sebanyak 9 orang. Kata kunci yang digunakan untuk mengetahui struktur kognitif mahasiswa pada konsep hukum Newton yaitu Gaya, Gerak, Kecepatan, Percepatan, Kelajuan dan Massa. Berdasarkan hasil analisis struktur kognitif mahasiswa kurang lengkap mahasiswa mengalami kesulitan dalam membedakan beberapa kata kunci, mengaitkan kata-kata kunci yang ada serta mahasiswa sulit dalam memberikan penjelasan mengenai kata-kata kunci. Hasil tes menunjukkan beberapa faktor yang mempengaruhi struktur kognitif mahasiswa, antara lain pengetahuan awal yang belum memadai, pemahaman konsep yang masih kurang, dan kecenderungan menghafal rumus tanpa pemahaman yang benar.
\end{abstract}

Kata kunci : Analisis, Struktur Kognitif, Hukum Newton

\section{PENDAHULUAN}

Piaget menyatakan bahwa pengetahuan dibangun sendiri oleh seseorang melalui proses asimilasi dan akomodasi. Dengan proses asimilasi seseorang mencoba untuk memahami lingkungannya menggunakan struktur kognitif atau pengetahuan yang sudah ada tanpa mengadakan perubahan-perubahan. Melalui proses akomodasi, seseorang mencoba memahami lingkungannya dengan terlebih dahulu memahami struktur kognitif yang sudah ada untuk membentuk struktur kognitif baru berdasarkan rangsangan yang diterima [1]

Ausubel menyatakan faktor yang paling penting yang mempengaruhi pembelajaran adalah struktur kognitif dan apa yang telah diketahui siswa, jadi supaya belajar bermakna, maka konsep baru harus dikaitkan dengan konsep- konsep yang ada dalam struktur kognitif. Proses belajar bermakna adalah terhubungnya ide-ide baru dengan struktur kognitif untuk membentuk pengetahuan baru. [2]

Struktur kognitif adalah bentuk rangkaian pemahaman peserta didik dalam menangkap keterkaitan antara konsep yang satu dengan konsep yang lainnya membentuk sebuah rangkaian konsep yang bermakna,[1]. Tujuan mengetahui struktur kognitif mahasiswa adalah untuk mengetahui sejauh mana tingkat pemahaman mahasiswa pada suatu materi yang telah diajarkan sebelumnya.

Mengetahui pemahaman konsep mahasiswa pada suatu materi, ini berarti kita mengetahui sejauh mana tingkat pengetahuan atau struktur kognitif mahasiswa pada suatu konsep yang telah diajarkan sebelumnya dan pengetahuan mereka bedasarkan pengalaman mereka. Seperti yang dinyatakan Fitrasari,D [3] faktor yang mempengaruhi dimensi proses kognitif siswa adalah pengetahuan awal yang belum memadai. Pengamatan yang tidak lengkap dan teliti dapat menyebabkan kesimpulan yang salah dan miskonsepsi.

Miskonsepsi atau kekeliruan konsep merupakan fenomena yang sampai sekarang masih menjadi permasalahan dalam pengajaran fisika maupun sains lainnya, karena keberadaannya dipercaya dapat menghambat proses asimilasi pengetahuan-pengetahuan baru pada benak para peserta didik. Miskonsepsi ini dapat terjadi pada semua tingkatan siswa, baik siswa SD sampai Mahasiswa bahkan guru juga dapat mengalami miskonsepsi, hal-hal yang menyebabkan terjadinya miskonsepsi diantaranya adalah tahap kognitif yang tidak sesuai dengan konsep yang dipelajari, penalaran mahasiswa yang terbatas dan salah, kemampuan mahasiswa menangkap dan memahami konsep 
yang dipelajari, dan minat Mahasiswa untuk mempelajari konsep yang diberikan dan diajarkan. [4] Adanya miskonsepsi ini jelas akan sangat menghambat proses penerimaan dan asimilasi pengetahuan-pengetahuan baru dalam proses belajar lebih lanjut. Klamer dalam [5]

\section{METODOLOGI PENELITIAN}

Penelitian ini merupakan penelitian deskriptif - kualitatif dimana semua data dikumpulkan berdasarkan fakta-fakta yang diperoleh di lapangan.

Penelitian ini dilakukan di lingkungan Program Studi Pendidikan Fisika, Jurusan Pendidikan MIPA Fakultas Keguruan dan Ilmu Pendidikan Universitas Tadulako, Palu. Waktu penelitian dilaksanakan pada bulan oktober 2015.

Subjek penelitian ini mahasiswa angkatan 2014 kelas C yang berjumlah 26 orang yang terdiri dari 9 orang laki-laki dan 17 orang perempuan.

Instrumen penelitian yang digunakan yaitu berupa tes kata kunci, dimana tes kata kunci yang diberikan adalah kata kunci dari konsep Hukum Newton yang telah dikonsultasikan dengan dosen pembimbing dan telah divalidasi. Tes kata kunci terdiri dari dua tahap: Tahap pertama, peserta di beri waktu untuk menuliskan 10 kata-kata pertama yang muncul di pikiran mereka setelah melihat kata kunci yang di sediakan. Tahap kedua, peserta di beri waktu untuk mendeskripsikan kata-kata kunci yang telah disediakan.

\section{HASIL DAN PEMBAHASAN}

Hasil penelitian struktur kognitif pada konsep hukum newton melalui tes kata kunci

\begin{tabular}{|c|c|c|}
\hline Kata kunci & Jawaban Subjek & $\begin{array}{l}\text { Jumlah } \\
\text { subjek }\end{array}$ \\
\hline \multirow[t]{11}{*}{ Gaya } & Gravitasi & 23 orang \\
\hline & Normal & 18 orang \\
\hline & Tarik - menarik & 15 orang \\
\hline & Gesek & 21 orang \\
\hline & Dorong & 12 orang \\
\hline & Aksi reaksi & 6 orang \\
\hline & Vertikal & 2 orang \\
\hline & Horisontal & 1 orang \\
\hline & Tolak menolak & 2 orang \\
\hline & m.a & 2 orang \\
\hline & Sentripetal & 3 orang \\
\hline \multirow[t]{5}{*}{ Gerak } & Partikel & 3 orang \\
\hline & Vertikal & 8 orang \\
\hline & Horisontal & 4 orang \\
\hline & Perubahan & 2 orang \\
\hline & Perpindahan & 2 orang \\
\hline \multirow[t]{6}{*}{ Kecepatan } & Konstan & 6 orang \\
\hline & $\mathrm{m} / \mathrm{s}$ & 1 orang \\
\hline & perpindahan & 1 orang \\
\hline & Vektor & 1 orang \\
\hline & $\mathrm{s} / \mathrm{t}$ & 2 orang \\
\hline & Benda & 5 orang \\
\hline \multirow[t]{6}{*}{ Percepatan } & Benda & 9 orang \\
\hline & Gravitasi & 4 orang \\
\hline & $\mathrm{m} / \mathrm{s}^{2}$ & 2 orang \\
\hline & Sentripetal & 1 orang \\
\hline & Kelajuan & 1 orang \\
\hline & Konstan & 6 orang \\
\hline \multirow[t]{5}{*}{ Kelajuan } & Benda & 9 orang \\
\hline & $x / t$ & 2 orang \\
\hline & Skalar & 5 orang \\
\hline & Jarak & 2 orang \\
\hline & $\mathrm{m} / \mathrm{s}$ & 2 orang \\
\hline \multirow[t]{3}{*}{ Massa } & Benda & 24 orang \\
\hline & $\mathrm{Kg}$ & 4 orang \\
\hline & $M$ & 2 orang \\
\hline Total & 34 kata & \\
\hline
\end{tabular}


Kalimat yang subjek penelitian tuliskan dari setiap kata kunci:

Pada Kata kunci gaya, kalimat yang sesuai dengan konsep hukum Newton adalah 25 orang, kalimat yang tidak sesuai dengan konsep hukum newton adalah 1 orang. Pada Pada kata kunci gerak kalimat yang sesuai dengan konsep hukum Newton adalah 19 orang, kalimat yang tidak sesuai dengan konsep hukum newton adalah 7 orang.

Pada kata kunci kecepatan, kalimat yang sesuai dengan konsep hukum Newton adalah 9 orang kalimat yang tidak sesuai dengan konsep hukum newton adalah 8 orang Mahasiswa dengan kalimat yang miskonsepsi adalah 9 orang.

Pada kata kunci percepatan kalimat yang sesuai dengan konsep hukum Newton adalah 11 orang, kalimat yang tidak sesuai dengan konsep hukum Newton adalah 15 orang

Pada kata kunci kelajuan kalimat yang sesuai dengan konsep hukum newton adalah 13 orang, kalimat yang tidak sesuia dengan konsep hukum Newton adalah 10 orang dan subjek penelitian dengan kalimat yang miskonsepsi adalah 3 orang Pada kata kunci Massa, kalimat yang sesuia dengan konsep hukum newton adalah 11 orang, subjek penelitian dengan kalimat yang miskonsepsi adalah 15 orang.

Berdasarkan penelitian yang telah dilakukan diperoleh informasi tentang struktur kognitif mahasiswa pada konsep hukum Newton dengan menggunakan tes kata kunci yakni gaya, gerak, kecepatan, percepatan, kelajuan dan massa.

Penelitian yang telah dilakukan dengan menggunakan tes kata kunci (WAT) menunjukkan ada mahasiswa yang mampu memberikan penjelasan dengan baik dan benar dari setiap kata kunci yang tersedia mahasiswa ini di anggap memiliki struktur kognitif yang telah lengkap mengenai konsep hukum Newton. Terdapat mahasiswa yang memberikan penjelasan yang tidak sesuai dengan konsep hukum Newton, mahasiswa yang mengalami miskonsepsi serta ada mahasiswa yang tidak memahami konsep yang ada.

Penelitian ini menunjukkan bahwa struktur kognitif mahasiswa pada konsep hukum Newton masih kurang lengkap hal ini terlihat pada hasil tes kata kunci dan wawancara yang telah dilakukan. Mahasiswa pada kategori baik belum memahami secara utuh mengenai kata kunci gerak dan kecepatan. Mahasiswa pada kategori cukup tidak bisa membedakan kata kunci kecepatan dan kelajuan serta tidak bisa mengaitkan setiap kata kunci yang ada meskipun mereka telah mengetahui rumusnya hal ini menunjukkan bahwa mereka hanya mengahafal rumus dan lebih ke segi matematis daripada pemahamankonsepnya. Mahasiswa pada kategori kurang tidak bisa memberikan penjelasan mengenai beberapa kata kunci yaitu kata kunci gerak, kecepatan massa, responden juga mengatakan bahwa kata-kata kunci yang ada saling berhubungan namun mereka tidak bisa untuk mengaitkan setiap kata kunci yang ada.

Permasalahan diatas terjadi dikarenakan mahasiswa melalui proses pembelajaran yang hanya menghafal konsep-konsep semata dan hanya sebatas menghitung untuk mendapatkan nilai yang tinggi, bukan belajar bermakna dengan menemukan sendiri konsep-konsepnya seperti yang dinyatakan oleh beberapa responden bahwa mereka pernah mempelajarinya namun lupa, dan tidak tahu di karenakan kurangnya pemahaman yang mendalam mengenai suatu materi, dalam penelitian ini mengenai konsep hukum Newton.

\section{- Mahasiswa dengan kategori baik}

\section{1) Kata kunci gaya}

Mahasiswa mampu menuliskan kalimat yang benar mengenai kata kunci gaya, dimana salah seorang responden menuliskan gaya menyebabkan suatu benda bisa berubah arah ataupun kecepatan. Responden lainnya menuliskan gaya adalah massa dikali dengan percepatan. Selanjutnya ketika dilakukan wawancara untuk mengkonfirmasi jawaban dan menggali lebih dalam mengenai pemahaman mahasiswa pada konsep hukum Newton responden mampu untuk memberikan contohcontoh penerapan gaya atau pengaruh gaya dalam kehidupan sehari-hari, serta mampu untuk mengaitkan kata kunci gaya dengan kata kunci lainnya seperti pada hasil kutipan wawancara berikut:

$\begin{array}{lll}\text { Peneliti } & \text { : } & \text { Apa yang (..) ketahui tentang } \\ \mathrm{R}-24 & \text { gaya? } & \\ & \text { gaya itu sesuatu yang } \\ \text { Peneliti } & \text { menyebabkan benda itu bisa } \\ \mathrm{R}-24 & : & \text { bergerak atau mengalami } \\ & \text { perubahan posisi begitu } \\ & \text { Bisa kamu memberikan contoh } \\ & \text { penerapan gaya? } \\ & \text { Contohnya itu misalnya ketika kita } \\ & \text { mendorong meja ataupun }\end{array}$

Peneliti : menarik benda begitu di situ kita melakukan gaya, gaya yang R-24: besarnya otomatis lebih besar Peneliti : dari gaya yang diberikan oleh 
R-24: meja, jadi ketika kita mendorong meja dan meja itu bergerak berarti gaya yang kita berikan itu lebih besar dari meja, berarti ada gaya aksi dan gaya reaksi.itu contoh salah satunya

Okk, dari keenam kata kunci yang tersedia ini adakah yang berhubungan dengan gaya Iya ada, terutama massa dan juga percepatan, tapi semuanya sih Jadi bagaimana hubungannya? kalau berdasarkan hukum II Newton $F=$ m.a, berarti berbanding lurus kak jadi ee semakin besar resultan gaya yang bekerja pada suatu benda maka percepatannya juga semakin besar begitu juga dengan massa kak.

\section{2) Kata kunci gerak}

Kata kunci ini responden mampu untuk menuliskan kalimat yang benar, mampu memberikan penjelasan mengenai pengaruh gerak dalam kehidupan sehari-hari namun belum mampu untuk memberikan penjelasan mengenai hubungan gerak, kecepatan dan massa dalam hukum I Newton hal ini terlihat pada kutipan wawancara berikut:

$$
\begin{array}{ll}
\text { Peneliti }: & \text { Bagaimana hubungan antara gerak, } \\
& \text { kecepatan, dan massa di dalam } \\
\mathrm{R}-11 & : \text { hukum I Newton? } \\
& \text { saya tidak tahu kak }
\end{array}
$$

\section{3) Kata kunci kecepatan}

Kata kunci ini hanya satu orang responden pada kategori baik yang menuliskan kalimat yang benar mengenai konsep kecepatan, $\mathrm{R}$ - 24 menuliskan kecepatan adalah perpindahan suatu benda setiap satuan waktu. selanjutnya ketika dilakukan wawancara R - 24 juga mampu memberikan penjelasan dengan baik. Berikut adalah kutipan wawancara:

Peneliti : Menurutmu apakah kecepatan dan $\mathrm{R}-24$ : kelajuan itu sama?

Beda kak, kalau kecepatan perpindahan artinya kita melihat posisi awal dan posisi akhir dibagi waktu tempuh kemudian jika kelajuan jarak total atau sama

Peneliti : dengan penjumlahan dari semua R-24 : jarak di bagi waktu. Misalnya lintasanya miring dari titik A ke titik
B kalau perpindahan itu melihat posisi awal dan posisi akhir, kalau

Peneliti : kelajuan penjumlahan dari jaraknya itu.

$\mathrm{R}-24$ : Bagaimana hubungan antara kecepatan, posisi dan waktu?

Kecepatan itu semakin besar perpindahannya maksudnya perubahan posisinya berarti semakin besar pula kecepatannya artinya kecepatan itu berbanding lurus dengan perpindahan dan berbanding terbalik dengan waktu. Oklah, nach kita bisa melihat kecepatan atau dapat mengetahui bahwa itu kecepatan itu dimana? Ketika kita naik motor dari satu tempat ke tempat lain, perpindahannya kita dari suatu tempat ke tempat lain di bagi dengan waktu.

\section{4) Kata kunci percepatan}

Responden pada kata kunci percepatan telah menuliskan kalimat yang benar dimana mereka menuliskan percepatan adalah perubahan kecepatan dibagi dengan waktu, namun ketika dilakukan wawancara $\mathrm{R}$ - 11 tidak bisa mengaitkan antara kata kunci percepatan dengan kecepatan dan waktu hal ini terlihat pada kutipan wawancara berikut:

Peneliti : bagaimana hubungan antara $\mathrm{R}-11$ : percepatan, kecepatan dan waktu? pas kak

\section{5) Kata kunci kelajuan}

Responden kategori baik telah menuliskan kalimat yang benar mengenai kata kunci kelajuan, dimana mereka menuliskan kelajuan adalah jarak dibagi dengan waktu dan salah seeorang responden lainnya menuliskan kelajuan adalah besaran skalar yang tidak memiliki arah namun memiliki besar. Selanjutnya dilakukan wawancara dua orang responden mampu memberikan penjelasan dengan baik dan benar mengenai perbedaan kelajuan dan kecepatan, dapat kita lihat pada hasil wawancara berikut:

Peneliti : kelajuan adalah jarak yang ditempuh tiap satuan waktu,itu kalimat yang (..) tuliskan kemarin

$\mathrm{R}-24$ : ya, na menurutmu apa yang kamu Peneliti : tulis ini sudah benar? Iya benar kak. Dari kalimat yang kamu tuliskan

R-24: sudah terlihat kalau kecepatan dan kelajuan itu berbeda nach, bisakah 
kamu menjelaskan lebih detail lagi tentang perbedaan kecepatan dan juga kelajuan?

Kecepatan adalah perpindahannya per satuan waktu, sedangkan kelajuan itu total jarak yang ditempuh oleh suatu benda yang bergerak/ satuan waktu. Misalnya ada seekor kuda mengitari lapangan kuda itu misalnya dari titik A kalau mengitari berarti kembali lagi ke titik $A$ kalau dia kecepatan berarti dikatakan kecepatan kuda nol $\mathrm{m} / \mathrm{s}$ karena kecepatan melihat posisi awal dan posisi akhir sedangkan dalam hal ini posisi awal dan posisi akhir sama misal posisi awal $X_{0}$ dan posisi akhir $X t$ jadi $X_{t}-X_{0}$ sama dengan nol jadi $0 / t$ berarti kecepatannya 0 , untuk kelajuan berarti kita hitung keliling lingkarannya itu per waktu.

\section{6) Kata kunci massa}

Kata kunci yang terakhir yakni massa, pada kata kunci ini responden pada kategori tinggi telah memahami dengan baik dan benar mengenai kata kunci ini. Responden mampu menuliskan kalimat yang benar mengenai kata kunci massa serta mampu untuk menghubungkan setiap kata kunci dan responden juga bisa membedakan massa dengan berat seperti pada hassil wawancara berikut:

Peneliti : di sini kamu menuliskan "massa adalah hasil bagi antara gaya dan percepatan yang terjadi".

$\mathrm{R}-17$ : Menurutmu apa yang kamu

Peneliti : tuliskan ini sudah benar?

R - 17 : untuk hukum II newton benar kak menurutmu apakah berat dan massa sama?

Peneliti : tidak sama kak, berat itu dipengaruhi oleg gaya gravitasi

$\mathrm{R}-17$ : kan rumusnya $W=m . g$, kalau massa sendiri tidak dipengaruhi oleh gaya gravitasi.

Bagaimana hubungan anatara massa, gaya, dan percepatan gravitasi?

kan rumusnya $F=$ m.a berarti gaya berbanding lurus dengan massa dan percepatan gravitasi.

\section{- Mahasiswa dengan kategori cukup}

\section{1) Kata kunci gaya}

Responden dengan kategori cukup telah menuliskan kalimat yang benar mengenai konsep gaya, seperti yang dituliskan oleh R - 06 gaya adalah berbanding lurus dengan massa dan percepatan suatu benda. Namun ketika dilakukan wawancara responden tidak bisa menghubungkan kata kunci gaya dengan kata kunci lainnya, berikut adalah kutipan wawancaranya:

Peneliti : kalimat yang (.....) tuliskan di sini adalah " $f=$ m.a( gaya adalah perkalian massa dan percepatan,

R-03: hukum II Newton" .menurutmu apa yang kamu tuliskan ini sudah

Peneliti : benar?

menurut saya itu sudah benar

R-03 : karena sudah sesuai dengan hukum II Newton.

bisakah kamu memberikan contoh

Peneliti : penerapan gaya dalam kehidupan sehari-hari?

R - 03 : seperti gaya gesek kan kalau kita mendorong lemari menghasilkan gaya gesek yaitu gaya gesek antara lantai dan lemari.

ok, nah dari keenam kata kunci yang tersedia ini adakah yang berhubungan dengan gaya? ada kayaknya tapi ndak tahu juga eee.

\section{2) Kata kunci gerak}

Responden mampu untuk menuliskan kalimat yang benar, dimana responden telah mengetahui pengaruh gerak dalam kehidupan sehari hari, namun responden kurrang memahami mengenai hubungan antara kecepatan, gerak dan massa di dalam hukum I Newton, berikut adalah hasil wawancara dengan salah seorang responden:

Peneliti : Bagaimana hubungan antara gerak kecepatan dan massa di

$\mathrm{R}-14$ : dalam hukum I Newton? aduhh bagaimana ya, ndak bisa saya kak

\section{3) Kata Kunci Kecepatan}

Salah seorang responden juga telah menuliskan kalimat yang benar, dan juga mengetahui persamaan kecepatan namun pemahaman $\mathrm{R}$ - 06 masih kurang karena ketika dilakukan wawancara responden tidak bisa memberikan penjelasan mengenai hubungan 
antara Posisi, kecepatan dan waktu, berikut adalah kutipan wawancaranya:

Peneliti : Membacakan kembali kalimat yang telah dituliskan "kecepatan adalah perpindahan per selang waktu

$\mathrm{R}-06$ : tertentu" menurutmu dek apa yang

Peneliti : kamu tuliskan ini sudah benar?

$\mathrm{R}-06$ : Iya benar karena kan $\mathrm{V}=\mathrm{S} / \mathrm{t}$

Ok, menurutmu apakah kecepatan dan kelajuan itu sama?

Peneliti : tidak, beda kak karena kalau $\mathrm{R}-06$ : kecepatan itu mempunyai nilai dan arah dan juga memiliki satuan sedangkan kelajuan besaran skalar begitu dant kak dia tidak memilki satuan.

Bagaimana hubungan antara kecepatan, posisi dan waktu?

Dari rumusnya itu kan $V=s / t$, bagaimana ya,, lewati jow kak hehheh

\section{4) Kata kunci percepatan}

Responden dengan kategori cukup telah menuliskan kalimat yang benar mengenai kata kunci percepatan, namun ketika dilakukan wawancara untuk menanyakan bagaimana hubungan antara percepatan, kecepatan dan waktu responden tidak bisa memberikan penjelasan mereka mengatakan bahwa mereka tidak tahu.

\section{5) Kata kunci kelajuan}

Sama halnya dengan kata kunci kecepatan responden tidak bisa membedakan kecepatan dan kelajuan, salah seorang respoden menuliskan kalimat kelajuan berbeda dengan kecepatan, namun ketika diwawancara responden mengatakan sebenarnya dia tidak mengetahui dengan jelas apa yang membedakan namun dia merasa itu berbeda, terlihat bahwa pemahaman responden masih kurang mengenai kelajuan.

Responden lainnya tetap mengatakan bahwa kecepatan dan kelajuan itu sama karena memilki persamaan yang sama. Salah seorang responden tidak menuliskan kalimat namun ketika di wawancara R-06 mampu memberikan penjelasan mengenai perbedaan kecepatan dan kelajuan berikut hasil wawancaranya:

Peneliti : Apa yang (...) ketahui tentang kelajuan, karena saya lihat di sini

R - $06 \quad$ kamu tidak menuliskan apa-apa di

Peneliti : kalimat yang terkait?

Saya tidak tahu kak hehehhe.

R-06: Menurutmu adakah yang membedakan kecepatan dengan kelajuan? Jika ada bisakah anda menjelaskannya?

ada, kecepatan itu besaran vektor

Peneliti : dan punya satuan sedangkan kelajuan itu besaran skalar, kan biasanya begini kak sebuah mobil dengan kecepatan begini dengan arah begini, tidak ada dikatakan sebuah mobil dengan kelajuan begini dan arah begini. ok..

\section{6) Kata kunci massa}

Responden tidak memahami dengan jelas tentang kata kunci massa mereka menuliskan massa adalah berat suatu benda, mereka beranggapan massa dan berat itu sama, ketika dilakukan wawancara salah seorang responden mengatakan massa dan berat sama, dan juga tidak bisa menghubungkan kata kunci massa dengan kata kunci lainnya berikut adalah kutipan wawancaranya:

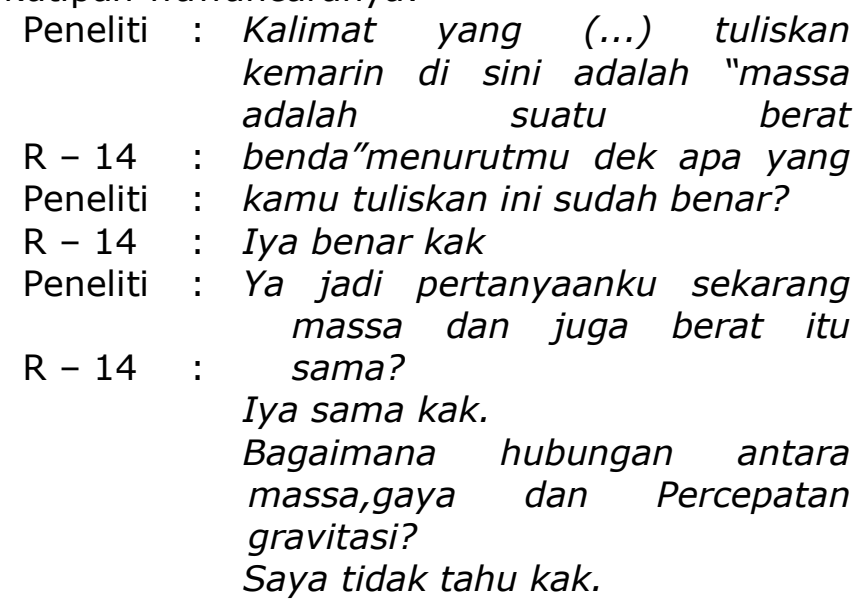

\section{- Mahasiswa dengan kategori kurang}

\section{1) Kata kunci gaya}

Kata kunci gaya dua orang responden yang menuliskan kalimat yang benar, mereka menuliskan gaya merupakan suatu yang menyebabkan suatu perubahan dan salah seorang lainnya menuliskan gaya merupakan perkalian antara massa dengan percepatan gravitasi, jika kita bergerak pasti menggunakan gaya.. Sedangkan R -21 menuliskan gaya berpengaruh terhadap hasil yang dipeoleh. Selanjutnya ketika dilakukan wawancara terlihat bahwa mereka kurang memahami hubungan gaya dengan kata kunci lainnya, berikut adalah kutipan wawancara dengan salah seorang responden :

Peneliti : Lanjut ya, menurutmu gaya ini termasuk dalam hukum Newton $\mathrm{R}-02$ : yang keberapa? 
Peneliti : Berapa eee... pertama stau kak kemudian, adakah dari keenam $\mathrm{R}-02$ : kata kunci yang saya sediakan ini Peneliti : yang berhubungan dengan gaya?

R-02 : Mempengaruhi semua, kalau kecepatan mempengaruhi gaya kak.

Ok nahh bagaimana hubungannya? Bagaimana eee..susah mau jelaskan kak, tapi pasti ada hubungannya itu kak.

Hal ini juga terjadi pada salah seorang responden lainnya, R - 08 mengatakan bahwa sebelumnya mereka telah mempelajari namun lupa, terlihat pada hasil wawancara berikut:

Peneliti : Dari keenam kata kunci yang tersedia ini adakah yang $\mathrm{R}-08$ : berhubungan dengan gaya?

Peneliti : Ada, tapi apa, ee gaya dengan

R-08 : jarak waktu percepatan.

Yaa jadi bagaimana
hubungannya?
Lupa saya kak, ada waktu itu.

\section{2) Kata kunci gerak}

Kata kunci yang kedua yakni gerak, pada kata kunci ini responden tidak menuliskan kalimat pada saat tes dilakukan ini menandakan bahwa responden kurang memahami mengenai konsep gerak dan pengaruh gerak dalam kehidupan sehari -hari, hal ini sesuai dengan hasil wawancara dengan R - 02 berikut adalah kutipan wawancara:

Peneliti : Kenapa sampai (...) tidak $\mathrm{R}-02$ : menuliskan apa-apa tentang

Peneliti : gerak? lupa kak..

R-02 : nah kalau sekarang saya tanya

Peneliti : apa yang kamu ketahui tentang gerak?

$\mathrm{R}-02$ : apa ee... heehheh

Peneliti : ok kita lanjut ya, menurutmu apa

$\mathrm{R}-02$ : yang menyebabkan benda itu

Peneliti : bergerak?

$\mathrm{R}-02$ : karena adanya gaya karena

Peneliti

$\mathrm{R}-02$

Peneliti

$\mathrm{R}-02$

Peneliti

$\mathrm{R}-02$

\section{adanya pergeseran}

ketika kita bergerak apa yang berubah?

apa ee.. tahu juga...

adakah hubungan antara gerak dengan kecepatan?

ada, tapi saya tidak tahu

jika ada kecepatan ada apa?

saya tidak tahu.

ketika kita bergerak apakah massa kita berubah atau tidak? massa berubah kak

Bagaimana hubungan antara gerak kecepatan dan massa di dalam hukum I Newton?

saya tidak tahu kak

\section{3) Kata kunci kecepatan}

Sama halnya dengan kata kunci gerak, pada kata kunci kecepatan responden dengan kategori kurang tidak menuliskan kalimat yang terkait. Pada saat dilakukan wawancara responden mengatakan bahwa kecepatan dan kelajuan itu berbeda namun mereka tidak bisa memberikan penjelasan mengenai perbedaan kecepatan dan kelajuan, serta responden tidak mampu untuk mengaitkan kata kunci kecepatan dengan kata kunci lainnya, berikut ini adalah kutipan wawancaranya:

Peneliti : ya jadi kemarin di lembar $\mathrm{R}-08$ : jawabannya (..) untuk kecepatan Peneliti : kamu tidak menuliskan kalimat $\mathrm{R}-08$ : yang terkait, kenapa bisa begini?

Peneliti : karena saya tidak tahu kak.

$\mathrm{R}-08$ : ok, menurutmu apakah kecepatan

Peneliti : dan kelajuan itu sama?

R-08 : beda kak, kalau kecepatan itu percepatannya itu sama, tapi kalau kelajuan itu percepatannya bertambah itu mungkin kak.

Bagaimana hubungan antara kecepatan, posisi, dan waktu?

apa e, ada itu rumusnya tapi saya lupa.

R -02 juga mengatakan bahwa kecepatan dan kelajuan berbeda namun responden tidak bisa memberikan penjelasan mengenai perbedaan dari kecepatan dan kelajuan serta tidak mengetahui bagaimana hubungan antara kecepatan, posisi dan waktu, dapat kita lihat pada kutipan wawancara berikut:

Peneliti : Menurut (...) apa itu kecepatan?

$\mathrm{R}-02$ : Tidak tahu kak

Peneliti : menurutmu apakah kecepatan dan $\mathrm{R}-02$ : kelajuan itu sama?

Peneliti : sama tapi ada pasti bedanya

$\mathrm{R}-02$ : Jadi apa yang membedakan? Kecepatan dan kelajuan, apa eee

Peneliti : kurang tahu saya kak, yang jelas R-02 : ada kayaknya bedanya itu. bagaimana hubungan antara Kecepatan, posisi dan waktu? Ada rumus kecepatan jarak : waktu, bagaimana hubungannya eee, saya tidak tahu kak. 


\section{4) Kata kunci percepatan}

Kalimat yang responden tuliskan untuk kata kunci percepatan sudah benar, namun pada saat dilakukan wawancara responden tidak yakin dengan kalimat yang dia tuliskan dan juga responden tidak bisa mengaitkan kata kunci percepatan dengan kata kunci lainnya, berikut ini adalah kutipan wawancaranya:

Peneliti : Membacakan kembali kalimat yang telah dituliskan oleh responden "semua benda yang bergerak

$\mathrm{R}-02$ : mempunyai percepatan"

Peneliti : menurutmu kalimat yang kamu

$\mathrm{R}-02$ : tuliskan ini sudah benar?

Peneliti : kayaknya kurang benar kak, R-02 : kayaknya..

Peneliti : adakah hubungan antara

$\mathrm{R}-02:$ ada percepatan, gaya dan massa?

nah bagaimana hubungannya?

saya tidak tahu kak

ok kita lanjut, bagaimana hubungan antara percepatan, kecepatan dan waktu?

saya tidak tahu kak heheeh

Salah seorang responden mengatakan percepatan, gaya dan massa saling berhubungan namun ketika ditanya bagaimana kaitannya, responden tidak bisa memberikan penjelasan.

\section{5) Kata kunci kelajuan}

Responden pada kata kunci kelajuan memiliki pemahaman yang salah,dimana responden menuliskan kelajuan merupakan vektor yang memiliki arah. Setelah dilakukan wawancara resonden mengatakan bahwa kalimat yang dia tuliskan sudah benar serta mengatakan bahwa kelajuan dan kecepatan itu berbeda namun tidak mengetahui apa perbedaannya, berikut adalah kutipan wawancaranya:

Peneliti : peneliti membacakan kembali kalimat yang responden tuliskan "vektor yang memiliki R-02 : arah"menurutmu dek apa yang Peneliti : kamu tuliskan ini sudah benar? Benar kak.

$\mathrm{R}-02$ : ok nah menurut (...) adakah yang membedakan kecepatan dengan kelajuan jika ada bisakah anda mejelaskannya?

Ada kak, tapi saya tidak tahu apa dia punya perbedaan.

\section{6) Kata kunci massa}

Kata kunci ini responden tidak menuliskan kalimat, pada saat dilakukan wawancara responden mengatakan massa adalah berat benda dan responden juga mengatakan bahwa massa dan berat berbeda namun sama seperti kata-kata kunci sebelumnya responden juga tidak mengetahui apa yang membedakan massa dengan berat.

Salah seorang responden lainnya mengatakan bahwa massa dan berat berbeda, dimana massa dipengaruhi oleh gaya gravitasi sedangkan berat tidak, hal ini menunjukkan pemahaman responden mengenai massa masih sangat kurang, berikut ini adalah kutipan wawancaranya:

Peneliti : Apakah massa dan berat itu sama?

$\mathrm{R}-21$ : Beda kak massa dipengaruhi oleh gravitasi, berat tidak di pengaruhi

Peneliti : oleh gravitasi

$\mathrm{R}-21$ : Ohh seperti itu ya?

Peneliti : Iya

$\begin{aligned} \mathrm{R}-21: & \text { Bagaimana hubungan antara } \\ & \text { massa, gaya dan percepatan } \\ & \text { gravitasi? } \\ & \text { Kalau gravitasinya besar maka } \\ & \text { massanya juga semakin besar, } \\ & \text { mungkin begitu. }\end{aligned}$

Ausubel menyatakan pembelajaran bermakna terjadi apabila peserta didik menghubungkan fenomena baru kedalam struktur kognitif mereka, artinya bahan subjek mesti relevan dengan struktur kogitif yang dimiliki peserta didik. Diharapkan melalui proses pembelajaran bermakna tersebut dapat membuat pemahaman konsep peserta didik lebih baik dan tidak terjadi kesalahpahaman terhadap suatu konsep, sehingga dapat meningkatkan pemahaman konsep peserta didik. [6]

Klamer mengatakan adanya miskonsepsi jelas akan menghambat proses penerimaan dan asimilasi pengetahuan-pengetahuan baru dalam proses belajar lebih lanjut [5]. Miskonsepsi,menghambat pembentukan pengetahuan pada struktur kognitif. Miskonsepsi yang dialami oleh responden dalam penelitian ini dikarenakan pengetahuan awal yang kurang memadai dan responden yang cenderung menghafal rumus tanpa pemahaman konsep yang benar [4]. Hal ini sesuai dengan pernyataan suprijono [7] yang menyatakan proses mengolah pengetahuan membutuhkann penalaran yang benar dan lengkap dalam prosesnya, pengamatan yang tidak lengkap dan teliti akan menyebabkan kesimpulan yang salah dan miskonsepsi.

Melalui penggunaan tes kata kunci (Word association test) untuk mengetahui struktur kognitif mahasiswa mengungkap apa yang telah diketahui mahasiswa, pemahaman mahasiswa 
mengenai konsep hukum Newton dan juga mengungkap bahwa masih ada mahasiswa yang mengalami miskonsepsi pada beberapa kata kunci. Penelitian Mutakim, [8]untuk melihat bagaimana struktur kognitif siswa pada pokok bahasan getaran gelombang dengan menggunakan evaluasi peta konsep mengatakan bahwa Ada empat kegunaan penting dari peta konsep, yaitu:

1) menyelidiki apa yang telah diketahui oleh siswa

2) untuk belajar tentang bagaimana belajar;

3) untuk mengungkapkan konsepsi salah (dapat menunjukkan adanya miskonsepsi siswa);

(4 sebagai alat evaluasi.

Penelitian ini dengan menggunakan tes kata kunci dan penelitian Mutakim [8] dengan menggunakan evaluasi peta konsep menunjukkan bahwa penggunaan kedua tes ini memiliki peranan yang sama, dimana melalui kedua tes ini peserta didik diharapkan menghubungkan antara konsep-konsep untuk menolong pendidik mengetahui konsep-konsep yang telah dimiliki para peserta didik agar belajar bermakna dapat berlangsung, untuk mengetahui penguasaan konsep-konsep pada peserta didik dan untuk menolong para peserta didik dalam belajar.

\section{DAFTAR PUSTAKA}

[1] Musabela, G. (2011). Pengembangan PerangkatEvaluasiPeta Konsep (PEPK) Untuk Mengukur Struktur Kognitif Siswa Kelass VIII Pada Pokok Bahasa Bunyi Di SMP Negeri 24 Semarang. Skripsi tidak diterbitkan. Semarang. Universitas Negeri Semarang.

[2] Surprianto. 2010. Pengembangan Evaluasi Peta Konsep Model C untuk Mengukur Struktur Kognitif pada Pokok Bahasan Besaran Fisika. Jurnal, volume 1 No.2

[3] Fitrasari,D (2014). Analisis Dimensi Proses Kognitif Kategori Mengevaluasi (C5) Siswa SMAN 4 Palu Tentang Konsep Listrik Dinamis. Skripsi tidak diterbitkan. Palu. Universitas Tadulako.

[4] Mahendrawan,E. (2012).Upaya Mengatasi Miskonsepsi Siswa Melalui Metode Pembelajaran Delikan ( Dengar, Lihat, Kerjakan ) Pada Siswa Kelas Viii Semester Genap Smp Muhammadiyah 2 Surakarta. Skripsi tidak diterbitkan. Surakarta. Universitas Muhammadiyah.

\section{KESIMPULAN}

Berdasarkan hasil penelitian dan pembahasan diketahui bahwa struktur kognitf mahasiswa belum lengkap, mahasiswa masih mengalami kesulitan dalam membedakan beberapa kata kunci, mengaitkan kata-kata kunci yang ada serta mahasiswa sulit dalam memberikan penjelasan mengenai kata-kata kunci.

Mahasiswa dengan kategori baik belum bisa mengaitkan kata kunci gerak dengan kata kunci lainnya dan responden tidak mengetahui perbedaan kecepatan dan kelajuan.

Mahasiswa pada kategori cukup belum bisa mengaitkan setiap kata kunci yang ada, tidak bisa membedakan kata kunci kecepatan dan kelajuan, serta mereka mengatakan bahwa massa dan berat tidak berbeda.

Mahasiswa dengan kategori kurang belum bisa mengaitkan kata-kata kunci yang ada, responden juga tidak bisa memberikan penjelasan mengenai kata kunci gerak dan kecepatan, serta responden tidak bisa memberikan penjelasan mengenai perbedaan kecepatan dan kelajuan.

[5] Widodo,S. (2012). Pengembangan Intrumen Evaluasi MiskoBerbasinsepsi Fisika Mahasiswa Dengan Menggunakan Certainty Of Response Index Berbasis CAA (Computer Aided Asessment). Yogyakarta: Universitas Islam Negeri Sunan Kalijaga.

[6] Suprijono. Agus. 2009.Cooperative Learning.Surabaya :Pustaka Belajar.

[7] Suprianto. 2010. Pengembangan Evaluasi Peta Konsep Model C untuk Mengukur Struktur Kognitif pada Pokok Bahasan Besaran Fisika. Jurnal, volume 1 No. 2

[8] Mutakim, C. (2011).Pengembangan Evaluasi Peta Konsep Sebagai Alat Ukur Struktur Kognitif Siswa Kelas VIII MT.S Pada Pokok Bahasan Getaran Dan Gelombang.Skripsi tidak diterbitkan.Semarang.Universitas Negeri Semarang. 